\section{New insights into steroidogenesis in normo- and hyperandrogenic polycystic ovary syndrome patients}

\author{
Novos aspectos na esteroidogênese em pacientes normo ou \\ hiperandrogênicas com síndrome de ovários policísticos
}

Sebastião Freitas de Medeiros ${ }^{1,2,3}$, Ângelo Barrionuevo Gil-Junior ${ }^{2}$, Jacklyne Silva Barbosa ${ }^{3}$, Érico Duarte Isaías², Márcia Marly Winck Yamamoto ${ }^{3}$
Department of Gynecology and Obstetrics at Medical Science School, Universidade Federal de Mato Grosso (UFMT), Cuiabá, MT, Brazil 2 Julio Muller University Hospital, Cuiabá, MT, Brazil ${ }^{3}$ Tropical Institute of Reproductive Medicine and Menopause, Cuiabá, MT, Brazil nedione (A) ( $p=0.0005$ and $p=0.047$, respectively) compared to normoandrogenic patients. delta $5(\Delta 5)$ pathway, the 17-hydroxylase and 17,20 lyase enzymes showed similar activities in both groups. Hyperandrogenic patients presented lower 21-hydroxylase, lower $11 \beta$-hydroxylase ( $p=$

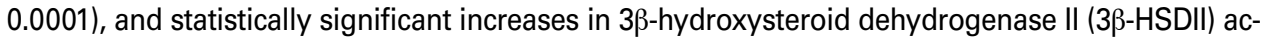
tivities $(p<0.0001)$. Following tetracosactrin stimulation, only the 17,20 lyase activity remained up-regulated in the $\Delta 4$ pathway $(p<0.0001)$. Conclusion: Hyperandrogenic patients had higher 17,20 lyase activity, both at baseline and after adrenal stimulation. Greater conversion of dehydroepiandrosterone (DHEA) into A with normal conversion of 17-OHPE to 17-OHP4 in hyperandrogenic PCOS patients indicated different levels of $3 \beta$-HSDIl activity in adrenal cells, and hyperandrogenic patients had lower 11 $\beta$-hydroxylase and 21-hydroxylase activities. Arq Bras Endocrinol Metab. 2013;57(6):437-44

\title{
Keywords
}

Polycystic ovary syndrome; steroidogenesis; hyperandrogenism; enzyme activity; adrenal stimulation

\section{RESUMO}

Objetivo: 0 objetivo deste estudo foi examinar a atividade de enzimas responsáveis pela produção de corticosteroides em pacientes normo e hiperandrogênicas com síndrome de ovários policísticos (SOP). Sujeitos e métodos: A coorte estudada incluiu 81 pacientes com hiperandrogenismo bioquímico e 41 pacientes com níveis normais de androgênio. A atividade enzimática foi avaliada de acordo com as proporções de produto/precursor do esteroide sérico, no momento inicial do estudo e depois de estimulação adrenal. Resultados: No momento inicial, na via delta $4(\Delta 4)$, as pacientes hiperandrogênicas mostraram maior atividade da 17-hidroxilase e 17,20 liase na conversão da progesterona (P4) em 17-hidroxiprogesterona (17-OHP4) e na conversão da 17-hidroxipregnenolona (17-OHPE) em androstenediona (A) $(p=0,0005$ e $p=0,047$, respectivamente) em comparação com pacientes normoandrogênicas. Na via delta $5(\Delta 5)$, a 17-hidroxilase e a 17,20 liase mostraram atividades similares nos dois grupos. As pacientes hiperandrogênicas mostraram menor atividade da 21-hidroxilase, menor atividade da $11 \beta$-hidroxilase $(p=0,0001)$ e aumento estatisticamente significativo na atividade da $3 \beta$-hidroxiesteroide desidrogenase II (3ß-HSDII) $(p<0.0001)$. Após a estimulação com tetracosactrin, apenas a atividade da 17,20 liase permaneceu regulada para cima na via $\Delta 4(p<0.0001)$. Conclusão: As pacientes hiperandrogênicas apresentaram atividade mais alta da 17,20 liase, tanto no momento inicial quanto depois da estimulação adrenal. Maior conversão da desidroepiandrosterona (DHEA) em A com conversão normal da 17-OHPE em 17-OHP4 em pacientes hiperandrogênicas com SOP indica níveis diferentes de atividade da $3 \beta$-HSDII em células da adrenal, e pacientes hiperandrogênicas apresentaram menores atividades da 11/-hidroxilase e da 21-hidroxilase. Arq Bras Endocrinol Metab. 2013;57(6):437-44

\section{Descritores}

Síndrome dos ovários policísticos; esteroidogênese; hiperandrogenismo; atividade enzimática; estimulação adrenal

Correspondence to: Sebastião Freitas de Medeiros Rua Almirante Henrique Pinheiro Guedes, 195

78043-306 - Cuiabá, MT, Brazil de.medeiros@terra.com.br

Received on Jan/24/2013 Accepted on Apr/22/2013 


\section{INTRODUCTION}

$\mathrm{P}$ atients with polycystic ovary syndrome (PCOS) have an increased luteinizing hormone (LH) pulse frequency, higher LH pulse amplitude, and greater secretion of ovarian testosterone $(\mathrm{T})$ and androstenedione (A). As the action of follicle-stimulating hormone $(\mathrm{FSH})$ is not increased, there is a relatively lower aromatization of these androgens in the granulosa cells of PCOS patients (1). PCOS patients also seem to have generalized adrenal hyperactivity and higher adrenal androgen secretion as a consequence of greater hormone adrenocorticotrophic (ACTH) action (2) or acceleration in cortisol (F) catabolism (3). Following the most recent standardization of diagnostic criteria (4-6), biochemical hyperandrogenism was found in $75 \%-82 \%$ of PCOS patients $(7,8)$. Short- and long-term metabolic consequences of biochemical hyperandrogenism require that the androgen levels and the source of such androgens be determined to provide a rationale for prognosis and the establishment of optimal therapy.

Androgen synthesis requires the action of the cholesterol side-chain cleavage (P450 ssc, CYPllA) and cytochrome P450cl7 $\alpha$ (CYP17) enzymes. The CYPl7 enzyme mediates both 17-hydroxylase and 17,20 lyase activities, with greater 17-hydroxylase activity in the adrenal fasciculate layer and equivalent activities in the reticular layer. The 17-hydroxylase enzyme promotes rapid conversion of pregnenolone (PE) and progesterone ( $\mathrm{P} 4)$ into 17-hydroxypregnenolone (17-OHPE) and 17-hydroxyprogesterone (17-OHP4), respectively; in tandem, and more slowly, 17,20 lyase converts 17-OHPE and 17-OHP4 into dehydroepiandrosterone (DHEA) and A, respectively (9). Two other adrenal enzymes, $3 \beta$-hydroxysteroid dehydrogenase II ( $3 \beta$-HSDII) and sulfotransferase (SULT2Al), drive these precursors towards the synthesis of A and dehydroepiandrosterone sulfate (DHEAS), respectively $(9,10)$.

After excluding classic 21-hydroxylase, $3 \beta$-HSDII, and $11 \beta$-hydroxylase deficiencies, thyroid dysfunctions, hyperprolactinemia, small defects, or imbalanced enzyme activities may account for the biochemical hyperandrogenism seen in PCOS patients $(9,11,12)$. Currently, few studies have investigated the activity of corticosteroidogenic enzymes in this syndrome (13), and these studies have not compared their results to those obtained in studies performed prior to the introduction of the NIH/Rotterdam diagnostic criteria. Considering the current exclusion criteria, differences in steroidogenic enzyme activities may exist between PCOS patients for whom diagnosis was performed before (11) or after the (14) NIH/ Rotterdam consensus. The present study sought to examine the activities of these enzymes in both normo- and hyperandrogenic PCOS patients in order to compare these new findings with those obtained prior to the National Institute of Health (NIH) meeting and the Rotterdam consensus.

\section{SUBJECTS AND METHODS}

One hundred and forty two PCOS patients diagnosed with PCOS were prospectively enrolled at the Júlio Muller University Hospital and Tropical Institute of Reproductive Medicine and Menopause in Cuiabá, MT, Brazil from January 2003 to August 2012. Each patient signed an informed consent form that was approved by the Federal University of Mato Grosso Committee for Ethics in Research. Patients who had used sex steroids or insulin sensitizing drugs over the last 6 months or who did not fulfill the NIH/Rotterdam criteria were excluded. Classic 21-hydroxylase, $3 \beta$-HSDII, and $11 \beta$-hydroxylase deficiencies were excluded in the following cases: 17-OHP4 levels $\leq 5 \mathrm{ng} /$ $\mathrm{mL}(\leq 15 \mathrm{nmol} / \mathrm{L}), 17-\mathrm{OHPE}<0.42 \mathrm{ng} / \mathrm{mL}(<13.5$ $\mathrm{nmol} / \mathrm{L})$, and $11-\mathrm{DOC}<8 \mathrm{ng} / \mathrm{mL}(<230 \mathrm{nmol} / \mathrm{L})$ $(12,15)$. Eighty-one patients had biochemical hyperandrogenism, and 41 had normal androgen levels. Despite normal baseline concentrations of 17-OHP4, 2 of these patients (one from each group) were subsequently excluded because their 17-OHP4 levels were > $30 \mathrm{nmol} / \mathrm{L}$ at $60 \mathrm{~min}$ after adrenal stimulation.

On average, included patients were $27.2 \pm 5.5$ years old. Anthropometric parameters were measured as previously described (8). Hyperandrogenism was defined as total $\mathrm{T} \geq 2.4 \mathrm{nmol} / \mathrm{L}, \mathrm{A} \geq 8.7 \mathrm{nmol} / \mathrm{L}$, DHEAS $\geq$ $6.7 \mathrm{nmol} / \mathrm{L}$, and free androgen index $(\mathrm{FAI}) \geq 7(8,16)$. The FAI was estimated as the total $\mathrm{T}(\mathrm{nmol} / \mathrm{L}) / \mathrm{sex}$ hormone-binding globulin (SHBG; nmol/L) x 100. The comparison between normo- and hyperandrogenic PCOS patients, as opposed to comparing PCOS subjects to healthy women, was consistent with recent recommendations (17).

In cases where the 17-OHP4 levels were $\geq 1$ and $<5$ $\mathrm{ng} / \mathrm{mL}$, a tetracosactrin stimulation test was performed; 21-hydroxylase enzyme deficiency was excluded if 17 OHP4 levels were $<10 \mathrm{ng} / \mathrm{mL}(30 \mathrm{nmol} / \mathrm{L})$ at $60 \mathrm{~min}$ after tetracosactrin stimulation (15). The tetracosactrin 
stimulation test was performed between 8:00 and 9:00 $\mathrm{AM}$ after a 12-hour fast. At baseline and 30 and $60 \mathrm{~min}$ after the injection of $0.25 \mathrm{mg}$ of tetracosactrin (Synacthen ${ }^{\circledast}$, Novartis Pharmaceuticals, NJ, USA), blood samples were collected and assayed for 17-OHP4, F, A, and $\mathrm{P} 4$. The adrenal response was evaluated by measuring the difference between the basal value and the highest value, divided by the basal value (maximum increment, $\Delta$ ) and the area under the curve (AUC).

Hormones were measured using previously validated methods. Serum P4 was measured using a chemiluminescence assay (Advia Centaur, Siemens Healthcare Diagnostics, UK) with a sensitivity of $0.67 \mathrm{nmol} / \mathrm{L}$ $(0.21 \mathrm{ng} / \mathrm{mL})$; coefficients of intra- and inter-assay variation were between $3.7 \%-12.4 \%$ and $2.6 \%-3.9 \%$, respectively. Serum LH, FSH, TSH, estradiol, PRL, SHBG, total T, and free thyroxin (FT4) were measured with an electrochemiluminescence assay (Elecsys 1010, Roche Diagnostics GmbH, Mannhein, German). The sensitivity and intra- and inter-assay coefficients of variation, respectively, were as follows: 0.1 $\mathrm{mUI} / \mathrm{L}$ and $1.8-3.4 \%$ for $\mathrm{LH} ; 0.1 \mathrm{mUI} / \mathrm{mL}$ and 1.8 $3.5 \%$ for $\mathrm{FSH} ; 18.4 \mathrm{pmol} / \mathrm{L}$ and $3.3-6.2 \%$ for estradiol; $0.002 \mathrm{nmol} / \mathrm{L}$ and $2.8-5.0 \%$ for PRL; $0.35 \mathrm{nmol} / \mathrm{L}$ and $2.6-5.6 \%$ for SHBG; $0.27 \mu \mathrm{Ul} / \mathrm{mL}$ and $2.1-8.6 \%$ for TSH; $0.069 \mathrm{nmol} / \mathrm{L}$ and $2.7-6.0 \%$ for total T; and $0.3 \mathrm{pmol} / \mathrm{L}$ and $3.6-6.2 \%$ for FT4. A, DHEAS, F, and insulin were measured using a chemiluminescence assay with a sensitivity of $1.0 \mathrm{nmol} / \mathrm{L}, 0.08 \mu \mathrm{mol} / \mathrm{L}, 5.5$ $\mathrm{nmol} / \mathrm{L}$, and $2 \mu \mathrm{UI} / \mathrm{mL}$, respectively (Siemens Medical Solution Diagnostics, CA, USA); the intra- and inter-assay precision coefficients of variation were $6.4 \%$ and $8.2 \%$ for $\mathrm{A} ; 4.9 \%$ and $8.8 \%$ for DHEAS; $5.8 \%$ and $8.6 \%$ for $\mathrm{F}$; and $4.9 \%$ and $6.4 \%$ for insulin. $17-\mathrm{OHP} 4$ levels were verified using a coat-a-count radioimmunoassay (Siemens Health Care Diagnostics Inc., CA, USA) with a sensitivity of $0.21 \mathrm{nmol} / \mathrm{L}$, and an interand intra-assay imprecision of $5.5 \%$ and $7.9 \%$, respectively. After extraction, 11-DOC was measured with an HPLC/RIA developed in-house by the Alvaro Center of Analysis and Clinical Research in Paraná, Brazil; the sensitivity was $0.3 \mathrm{nmol} / \mathrm{L}$, and the inter-assay coefficients of variation were $5.3 \%$ and $10.8 \%$. 17-OHPE was measured with an HPLC/RIA using tritiated steroids (NEN Life Science Products, Boston, MA, USA) and antiserum from ICN Biochemical Inc. (Costa Mesa, CA, USA); the sensitivity was $0.033 \mathrm{nmol} / \mathrm{L}$, and the intra- and inter-assay coefficients of variation were $8.9 \%$ and $11 \%$, respectively.
Data distribution was assessed by Shapiro-Wilkins test and those with nonparametric distribution were transformed into a logarithmic scale prior to analysis, and subsequently retransformed into the original units. Anthropometric, endocrine, and enzymatic activity results are presented as the mean $(\overline{\mathrm{x}})$ and standard deviation $(\mathrm{SD})$ and were analyzed using the Welch test. Clinical data were compared using a proportion test; $p$ values $\leq 0.05 \%$ were considered statistically significant.

\section{RESULTS}

Infertility $(20 \%$ vs. $50 \%)$ and secondary amenorrhea $(37.5 \%$ vs. $60 \%)$ tended to be more frequent in hyperandrogenic patients, although these differences were not statistically significant $(p=0.064$ and $p=0.117$, respectively). The rates of hirsutism, acne, acanthosis nigricans, and oligomenorrhea were also similar between normo- and hyperandrogenic patients, and no differences in age, BMI, waist/hip ratio, or body surface area were observed (Table 1 ).

Hyperandrogenic patients had higher basal levels of LH, T, A, DHEAS, 17-OHP4, 11-DOC, and insulin compared with normoandrogenic patients. Baseline concentrations of F, PRL, P4, E2, and thyroid hormones were similar in both groups (Table 2).

At the baseline condition, 17,20 lyase activity was not different between normoandrogenic and hyperandrogenic PCOS patients for the conversion of 17 OHPE into DHEA ( $\Delta 5$ pathway; Table 3 ). Hyperandrogenic patients demonstrated higher 17-hydroxylase (17-OHP4/P4 of 3.49 vs. $2.21 ; p=0.0005)$ and 17,20 lyase (A/17-OHP4 of 3.38 vs. $2.58 ; p=0.047)$ activities for the conversion of $\mathrm{P} 4$ to 17-OHP4 and 17-OHP4 to A, respectively ( $\Delta 4$ pathway). The $3 \beta$-HSDII enzyme demonstrated greater conversion of DHEA to A in hyperandrogenic patients (A/DHEAS of $3.02 v s .1 .52 ; p$ $<0.0001)$. In contrast, 17-OHPE was converted into 17-OHP4 at the same rate in both groups (17-OHP4 17-OHPE of $1.79 v s .1 .67 ; p=0.837)$. The activities of 21-hydroxylase (11-DOC/17-OHP4 of 1.0 vs. 2.2; $p<0.0001)$ and $11 \beta$-hydroxylase (F/11-DOC of 5.42 vs. $7.44 ; p=0.0001)$ were lower in hyperandrogenic patients (Table 3 ).

Following adrenal stimulation, the maximal levels of F, A, 17-OHP4, and P4 were not different between normo- and hyperandrogenic patients $(p>0.05)$. However, the areas under the response curves of 17 OHP4 and A were greater in hyperandrogenic patients 
Table 1. Anthropometric characteristics of normo-and hyperandrogenic PCOS patients

\begin{tabular}{|c|c|c|c|c|c|c|c|}
\hline \multirow{2}{*}{ Variable } & \multicolumn{3}{|c|}{ Normoandrogenic patients } & \multicolumn{3}{|c|}{ Hyperandrogenic patients } & \multirow{2}{*}{$p^{a}$} \\
\hline & n & $\overline{\mathrm{x}}$ & SD & n & $\overline{\mathrm{X}}$ & SD & \\
\hline Age (years) & 39 & 26.6 & 5.8 & 79 & 27.0 & 5.4 & 0.719 \\
\hline Weight (kg) & 38 & 74.6 & 25.6 & 75 & 75.4 & 16.3 & 0.861 \\
\hline Height (m) & 37 & 1.58 & 0.06 & 64 & 1.57 & 0.07 & 0.450 \\
\hline $\mathrm{BMl}$ & 37 & 29.0 & 10.0 & 64 & 30.6 & 6.5 & 0.386 \\
\hline Waist (cm) & 32 & 87.9 & 18.6 & 59 & 90.9 & 13.1 & 0.422 \\
\hline Hip (cm) & 32 & 106.6 & 16.9 & 59 & 107.7 & 12.8 & 0.749 \\
\hline W:H & 32 & 0.82 & 0.06 & 59 & 0.84 & 0.08 & 0.182 \\
\hline Body area $\left(m^{2}\right)$ & 37 & 1.76 & 0.3 & 64 & 1.81 & 0.2 & 0.369 \\
\hline
\end{tabular}

a Welch Test.

Table 2. Comparison of demographic and endocrine characteristics in patients with PCOS with and without hyperandrogenemia

\begin{tabular}{|c|c|c|c|c|c|c|c|}
\hline \multirow{2}{*}{ Hormone } & \multicolumn{3}{|c|}{ Normoandrogenic patients } & \multicolumn{3}{|c|}{ Hyperandrogenic patients } & \multirow{2}{*}{$p^{b}$} \\
\hline & $\mathbf{n}$ & $\overline{\mathbf{x}}$ & SD & $\mathbf{n}$ & $\overline{\mathbf{x}}$ & SD & \\
\hline TSH $(\mu \mathrm{Ul} / \mathrm{mL})$ & 36 & 2.50 & 1.31 & 72 & 2.19 & 1.16 & 0.233 \\
\hline Free thyroxine $(\mathrm{pmol} / \mathrm{L})^{\mathrm{a}}$ & 35 & 14.56 & 1.16 & 62 & 14.23 & 1.46 & 0.224 \\
\hline Prolactin (nmol/L) $)^{\star}$ & 37 & 0.48 & 0.25 & 75 & 0.43 & 0.21 & 0.268 \\
\hline $\mathrm{LH}(\mathrm{mUl} / \mathrm{mL})^{\mathrm{a}}$ & 38 & 6.66 & 1.91 & 74 & 9.32 & 1.69 & $<0.0001$ \\
\hline $\mathrm{FSH}(\mathrm{mUI} / \mathrm{mL})^{\mathrm{a}}$ & 38 & 6.10 & 1.49 & 74 & 5.64 & 1.39 & 0.118 \\
\hline LH:FSH ratio ${ }^{\mathrm{a}}$ & 38 & 2.57 & 1.54 & 74 & 2.85 & 1.41 & 0.352 \\
\hline Total testosterone $(\mathrm{nmol} / \mathrm{L})^{*}$ & 35 & 1.50 & 0.50 & 74 & 2.20 & 1.04 & $<0.0001$ \\
\hline SHBG (nmol/L) $)^{a}$ & 35 & 39.35 & 1.67 & 43 & 25.38 & 1.70 & $<0.0001$ \\
\hline FAl (\%) & 31 & 4.16 & 1.77 & 63 & 10.17 & 5.86 & $<0.0001$ \\
\hline Cortisol (nmol/L) $)^{*}$ & 35 & 347.80 & 139.40 & 78 & 358.90 & 172.10 & 0.717 \\
\hline 17-hydroxypregnenolone (nmol/L)* & 17 & 4.98 & 2.80 & 34 & 6.07 & 3.55 & 0.239 \\
\hline 17-hydroxyprogesterone $(\mathrm{nmol} / \mathrm{L})^{\mathrm{a}^{\star}}$ & 35 & 3.36 & 1.60 & 76 & 4.74 & 1.66 & $<0.0001$ \\
\hline 11-deoxycortisol (nmol/L) ${ }^{\text {a* }}$ & 32 & 61.3 & 17.3 & 44 & 72.9 & 17.1 & 0.004 \\
\hline DHEAS $(\mu \mathrm{mol} / \mathrm{L})^{*}$ & 36 & 3.74 & 1.54 & 71 & 5.31 & 2.70 & 0.0002 \\
\hline Androstenedione (nmol/L)* & 34 & 5.15 & 1.51 & 75 & 11.49 & 4.96 & $<0.001$ \\
\hline Estradiol (nmol/L) $)^{*}$ & 31 & 162.51 & 64.80 & 50 & 191.97 & 97.0 & 0.105 \\
\hline Progesterone $(\mathrm{nmol} / \mathrm{L})^{*}$ & 31 & 2.23 & 1.46 & 61 & 1.86 & 1.15 & 0.224 \\
\hline Insulin (pmol/L) & 32 & 61.29 & 1.92 & 71 & 82.14 & 1.96 & 0.0001 \\
\hline
\end{tabular}

${ }^{a}$ The data underwent logarithmic transformation to meet the Gaussian distribution precepts. ${ }^{b}$ Welch unpaired test.

* To convert gravimetric international unit (SI) values to mass units, we divided by 0.0347 for total T, 0.0271 for DHEAS, 0.0301 for 17-0HPE, 0.0303 for 17-0HP4, 0.0349 for A, 0.02886 for 11DOC, 27.59 for cortisol, 3.671 for estradiol, 3.18 for P4, 0.04348 for PRL, 12.87 for free thyroxine, and 6.945 for insulin.

Table 3. Corticosteroidogenic enzyme activity in normo-and hyperandrogenic patients with PCOS

\begin{tabular}{|c|c|c|c|c|c|c|c|c|}
\hline \multirow{2}{*}{ Enzyme } & \multirow{2}{*}{ Ratio $^{a}$} & \multicolumn{3}{|c|}{ Normoandrogenic patients } & \multicolumn{3}{|c|}{ Hyperandrogenic patients } & \multirow{2}{*}{$p^{c}$} \\
\hline & & $\mathbf{n}$ & $\overline{\mathrm{X}}$ & SD & $\mathbf{n}$ & $\overline{\mathrm{X}}$ & SD & \\
\hline \multicolumn{9}{|l|}{$\mathrm{P} 450 \mathrm{c} 17 \alpha$} \\
\hline 17, 20 lyase $(\Delta 5)\left(x 10^{3}\right)$ & DHEAS/17-OHPE & 16 & 2.19 & 1.05 & 30 & 0.95 & 1.98 & 0.415 \\
\hline 17-hydroxylase ( $\Delta 4$ pathway) & 17-0HP4/P4 & 30 & 2.21 & 1.45 & 58 & 3.49 & 1.76 & 0.0005 \\
\hline 17, 20 lyase ( $\Delta 4$ pathway) & A/17-OHP4 & 30 & 2.58 & 1.68 & 72 & 3.38 & 0.66 & 0.047 \\
\hline \multirow[t]{2}{*}{$3 \beta$-HSDII $\left(x 10^{-3}\right)$} & 17-OHP4/17-HOPE & 30 & 1.67 & 1.52 & 30 & 1.79 & 1.48 & 0.837 \\
\hline & A/DHEAS & 31 & 1.52 & 0.79 & 66 & 3.02 & 2.50 & $<0.0001$ \\
\hline $11 \beta$-hydroxylase & F/11-DOC & 29 & 7.44 & 0.16 & 42 & 5.42 & 0.19 & 0.0001 \\
\hline 21-hydroxylase & 11-DOC/17-OHP4 & 29 & 2.20 & 1.07 & 39 & 1.09 & 0.41 & $<0.0001$ \\
\hline 11 and 21-hydroxylase & $\mathrm{F} / 17-0 \mathrm{HP} 4^{\mathrm{b}}$ & 34 & 148.40 & 2.44 & 73 & 85.30 & 1.98 & $<0.0001$ \\
\hline $3 \beta$-HSDII, 11 and 21-hydroxylase & F/17-OHPE & 14 & 60.30 & 1.83 & 31 & 58.90 & 1.19 & 0.017 \\
\hline
\end{tabular}

${ }^{a}$ All the results are expressed in $\mathrm{nmol} / \mathrm{L}$. ${ }^{\mathrm{b}}$ The data underwent logarithmic transformation to meet the Gaussian distribution precepts. ${ }^{\mathrm{c}}$ Welch unpaired test. 
$(p<0.0001$ and $p=0.049$, respectively). Although they presented different activities under basal conditions after tetracosactrin stimulation, normoandrogenic and hyperandrogenic patients did not differ in their 17-hydroxylase activity for converting P4 into 17-OHP4 in the $\Delta 4$ pathway ( $p=0.134$; Figure 1$)$. On the other hand, 17,20 lyase activity for converting 17-OHP4 into A was greater in this pathway among hyperandrogenic women $(p<0.0001$; Figure 1). Sixteen out of $40(40 \%)$ normoandrogenic patients and 58 out of 80 hyperandrogenic patients showed baseline levels of 17-OHP4 $\geq 1.0$ and $<5.0 \mathrm{ng} / \mathrm{mL}$. All of these patients were subjected to adrenal stimulation, and after tetracosactrin injection, 2 out of 16 (12.5\%) normoandrogenic patients had 17-OHP4 levels between 15 and $30 \mathrm{nmol} / \mathrm{L}$; in the hyperandrogenic PCOS group, 11/58 (18.9\%) patients presented 17-OHP4 levels in this range $(p=0.551)$.

A

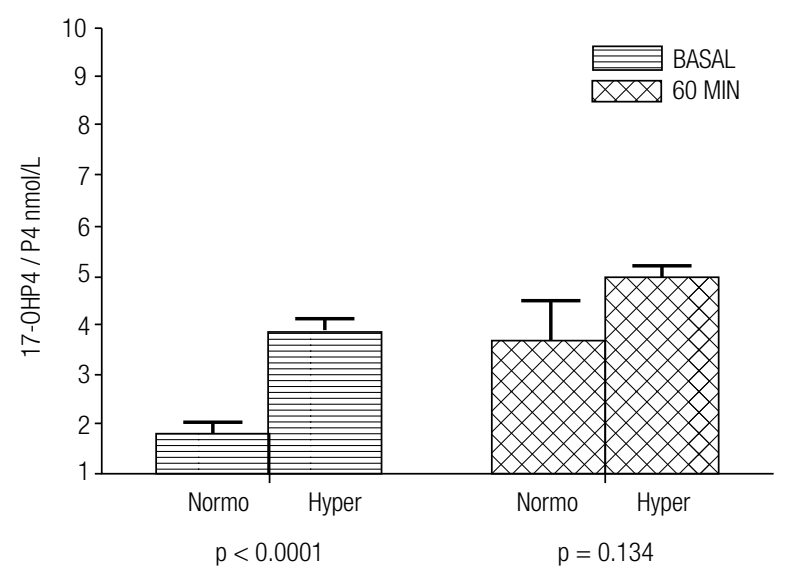

B

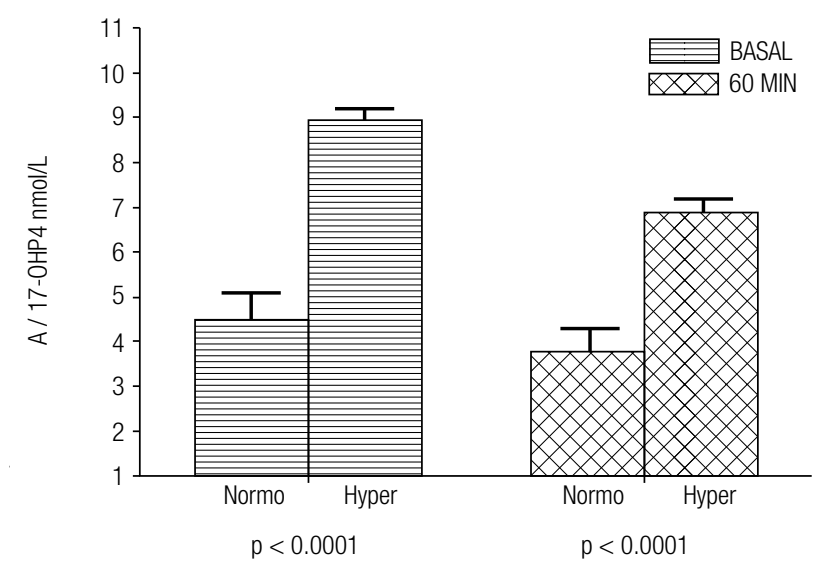

Figure 1. 17-hydroxylase $\triangle 4$ (17-OHP4/P4; panel A) and 17,20 lyase $\Delta 4$ (A/17-OHP4; panel B) activities before (basal) and after (60 min) tetracosactrin injection in normo- and hyperandrogenic PCOS patients.

\section{DISCUSSION}

The present study compared the activities of different steroidogenic enzymes between normoandrogenic and hyperandrogenic PCOS patients, rather than between PCOS and healthy subjects, as recently suggested (17), both before and after adrenal stimulation. To the best of our knowledge, this is the first study comparing corticosteroidogenic enzyme activities between normo- and hyperandrogenic PCOS patients. Previous studies have shown that a single early morning basal serum androgen measurement, as used in the current study, is an extremely accurate screening method (18). In previous studies, using several androgens as markers, biochemical hyperandrogenism was found in up to $80 \%$ of PCOS patients in different populations, as diagnosed using the $\mathrm{NIH} /$ Rotterdam criteria $(7,8)$. In addition, adrenal hyperandrogenism was found in up to $62 \%$ of PCOS patients (19), and ovarian hyperandrogenism was reported to be even more frequent (7). No consistent corticosteroidogenic enzyme abnormality has been reported in PCOS patients. After the introduction of the NIH/Rotterdam criteria in the clinical setting, only a few studies have examined the activities of these enzymes (14), so this was the principal goal of the current study.

A detailed understanding the $\Delta 4$ and $\Delta 5$ corticosteroidogenic pathways is illustrated in figure 2 (9). Dysregulation of the P450c17 $\alpha$ enzymatic complex in PCOS was reported previously, both before $(11,20)$ and after (21) dissemination of the NIH/Rotterdam criteria, at least in the presence of biochemical hyperandrogenism. In the current study, 17,20 lyase activity was higher for the conversion of 17-OHP4 into A in hyperandrogenic patients, both at baseline and after adrenal tetracosactrin stimulation. Both decreases in 17-hydroxylase activity with increases in 17,20 lyase (18) and increases in 17-hydroxylase in relation to 17,20 lyase (12) activity have been detected in PCOS patients, even after the adoption of the new exclusion criteria. An early study demonstrated that in PCOS patients, estrogen may activate 17,20 lyase for the conversion of 17-OHP4 into A without affecting the conversion of 17-OHPE into DHEA(13). The increase in 17,20 lyase activity was also seen in PCOS patients, even after diagnostic standardization, and it was attributed to the phosphorylation of Ser/Thr residues, cytochrome b5, and cytochrome c allosteric actions (22-24). In fact, $\mathrm{P} 450 \mathrm{cl} 7 \alpha$ dysregulation has been attributed to 
the modulatory effects of cytochrome b5, insulin, and estradiol $(13,23)$. In the current study, estradiol levels were not increased in the hyperandrogenic group, and this finding does not support previous observations indicating that estrogen may increase 17,20 lyase activity in the conversion of 17-OHP4 to A in PCOS patients $(13,14)$. Although hyperandrogenic patients presented higher baseline insulin levels, reports of the role of insulin in P450c17 $\alpha$ enzyme activity have been inconsistent $(13,23,25)$.

The higher baseline 17-OHP4 and A levels found in the hyperandrogenic patients in the present study indicate that PCOS patients with biochemical hyperandrogenism have greater 17-hydroxylase and 17,20 lyase activities in the $\Delta 4$ pathway, which results in greater conversion of $\mathrm{P} 4$ to $17-\mathrm{OHP} 4$ and 17-OHP4 to A (Figure 2). Higher baseline levels of DHEAS and 17OHPE in hyperandrogenic patients also indicate higher $\mathrm{P} 45017 \alpha$ complex activity in the $\Delta 5$ pathway. These observations are relevant because, in normal conditions, the human $\mathrm{P} 450 \mathrm{c} 17 \alpha$ enzyme possesses normal 17,20 lyase activity for the conversion of 17-OHPE to DHEA ( $\Delta 5$ pathway) but minimal, if any, activity for the conversion of 17-OHP4 to A ( $\Delta 4$ pathway) (26). Compared to healthy individuals, greater activity of 17,20 lyase was previously demonstrated in PCOS patients when they were diagnosed according to the
Rotterdam criteria and taken as the only population group (14). On the other hand, 17-hydroxylase activity was shown to be the same in both PCOS and healthy women (14). There is currently no clear explanation for this inconsistency, but it is possible that 17-hydroxylase activity may be maximally driven, precluding its further increase in the conversion of $\mathrm{P} 4$ to 17-OHP4.

Hyperandrogenic patients may present decreased $3 \beta$-HSDII activity with a lower conversion rate of $\Delta 5$ $3 \beta$-hydroxysteroids to $\Delta 4-3 \beta$-hydroxysteroids $(10,11)$, which results in a higher amount of substrates for androgen synthesis $(26,27)$. Prior to the NIH/Rotterdam criteria, a non-classic clinical form of $3 \beta$-HSD deficiency was reported in hyperandrogenic patients with hirsutism and abnormal menstrual cycles $(27,28)$, and different $3 \beta$-HSD activities have been reported in PCOS patients both before (27) and after the implementation of the Rotterdam criteria (26). In the current study, normo- and hyperandrogenic PCOS patients demonstrated equal ratios of progesterones (17-OHP4/17OHPE $p=0.837$, suggesting equal $3 \beta$-HSDII activity in these groups for the conversion of 17-OHPE to 17OHP4. Equivalent $3 \beta$-HSDII activity was previously reported for the comparison between healthy women and PCOS patients (13). Using DHEAS as a surrogate for DHEA, the higher A/DHEAS ratio in hyperandrogenic patients found in the current study suggests

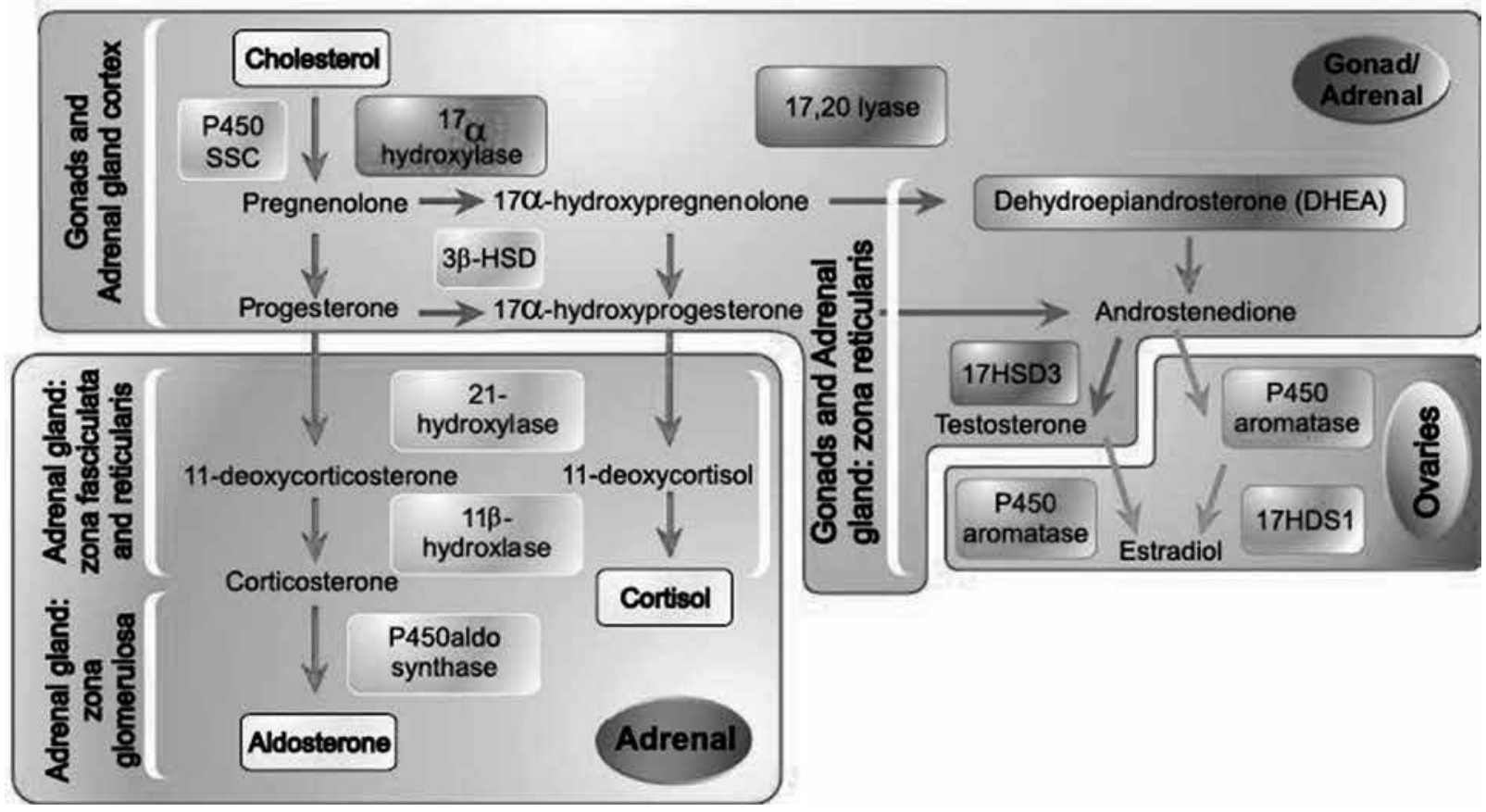

Figure 2. Adrenal and ovarian steroidogenesis. P450 ssc: cytochrome P450 cholesterol side-chain cleavage; 17 $\beta$ HSD3: 17-hydroxysteroid dehydrogenase III; 17ßHSD1: 17-hydroxysteroid dehydrogenase I. Modified from reference 9. 
higher $3 \beta$-HSDII activity specifically for the conversion of DHEA to A. This discrepancy and inconsistency in the $3 \beta$-HSDII activity indicates that this enzyme may not be similarly expressed in all adrenal cells (29).

Even prior to diagnostic standardization, lower 21-hydroxylase activity was found in 1\%-19\% of PCOS patients, depending on their ethnicity (30). In the present study, this lower activity was found only in hyperandrogenic patients for whom the 11-DOC/17OHP4 ratio was significantly lower in comparison to normoandrogenic patients. Thus, the present study supports the tendency for lower 21-hydroxylase activity in some PCOS patients, which was previously demonstrated both before (30) and after (31) the NIH/ Rotterdam standardization. A minor $11 \beta$-hydroxylase deficiency was found in up to $8.4 \%$ of PCOS patients prior to NIH/Rotterdam standardization (13). In the present study, $10 \%(4 / 40)$ of the hyperandrogenic PCOS patients presented 11-DOC concentrations of $18.2 \mathrm{nmol} / \mathrm{L}$, a threefold increase compared with the third quartile of the normoandrogenic patients, indicating some degree of $11 \beta$-hydroxylase deficiency. Similar results were previously observed when hyperandrogenic PCOS patients were compared to normal women (12). In addition, in the current study, hyperandrogenic patients had lower C/11-DOC ratios with 11-DOC accumulation, and these findings support earlier observations of lower $11 \beta$-hydroxylase activity in a group of clomiphene-resistant PCOS patients (11). A significant decrease in the conversion of 17-OHP4 to $\mathrm{C}$, representing the combined activities of 11-hydroxylase and 21-hydroxylase, was present only in hyperandrogenic patients in the present study. After the NIH/ Rotterdam standardization, the combined activities of these enzymes, as examined by the C/17-OHP4 ratio, were reported to be the same when PCOS patients as a whole were compared to healthy, normal cycling women (32). These discrepancies indicate that the decreased combined activities of 11-hydrolase and 21-hydroxylase may occur only in hyperandrogenic PCOS patients and reinforce the notion that PCOS patients with hyper- and normoandrogenic phenotypes should be examined separately.

Most anthropometric and clinical aspects are not thought to differentiate normoandrogenic from hyperandrogenic PCOS patients. Dysregulation of the $\mathrm{P} 450 \mathrm{c} 17 \alpha$ enzymatic complex with up-regulated 17,20 lyase activity was found only in the hyperandrogenic PCOS group, both at baseline and after adrenal stimulation. The greater conversion of DHEA into A that was observed in hyperandrogenic PCOS patients without an increased conversion rate of 17-OHPE to 17-OHP4 supports previous reports of different $3 \beta$-HSDII activities in different adrenal cells. Hyperandrogenic PCOS patients have lower 21-hydroxylase and $11 \beta$-hydroxylase activities than normoandrogenic patients, and the results of the current study confirm findings reported prior to the $\mathrm{NIH} /$ Rotterdam diagnostic criteria. Taken together, the findings of this study and those of other publications with a similar design suggest the existence of different pathophysiologies in normo- and hyperandrogenic PCOS patients.

Although the present study clearly defined PCOS and biochemical hyperandrogenism, it may have suffered from some limitations. First, the criteria used to exclude classic 21 -hydroxylase, 11 $\beta$-hydroxylase, and $3 \beta$-HSD deficiencies are not yet standardized, and those used in this study may be not universally adopted. Second, the use of the A/DHEAS ratio as a surrogate for the A/DHEA ratio to evaluate $3 \beta$-HSDII activity may not be appropriate. However, DHEAS and DHEA levels have been shown to be closely related $(9,28)$, and an advantage of measuring DHEAS is that it is stable throughout the day. Third, the assays used to measure androgens may not be very accurate; however, recent comparisons between early radioimmunoassays for $\mathrm{T}$, 17-OHPE, 17OHP4, 11-DOC, and liquid chromatography tandem mass spectrometry have shown good agreement between the methods (33). Fourth, the comparison of enzyme activities between normo- and hyperandrogenic PCOS patients, as opposed to comparing PCOS patients to healthy women, was selected due to recent recommendations that provided new information on the phenotypic heterogeneity seen in PCOS patients.

Acknowledgements: the authors would like to thank the American Journal Experts for English review of the manuscript.

Disclosure: no potential conflict of interest relevant to this article was reported.

\section{REFERENCES}

1. Gilling-Smith $C$, Story $H$, Rogers V, Franks S. Evidence for a primary abnormality of thecal cell steroidogenesis in the polycystic ovary syndrome. Clin Endocrinol. 1997;47:93-9.

2. Moran C, Reyna R, Boots LS, Azziz R. Adrenocortical hyperresponsiveness to corticotrophin in polycystic ovary syndrome patients with adrenal androgen excess. Fertil Steril. 2004;81:126-31. 
3. Gambineri A, Forlani G, Munarini A, Tomassoni F, Cognigni GE, Ciampaglia W, et al. Increased clearance of cortisol by 5beta-reductase in a subgroup of women with adrenal hyperandrogenism in polycystic ovary syndrome. J Endocrinol Invest. 2009;32:210-8.

4. The Rotterdam ESHRE/ASRM-Sponsored PCOS Consensus Workshop Group. Revised 2003 consensus on diagnostic criteria and long-term health risks related to polycystic ovary syndrome. Fertil Steril. 2004;81:19-25.

5. Zawadski JK, Dunaif A. Diagnostic criteria for polycystic ovary syndrome: towards a rational approach. In: Dunaif AGJ, Haseltine F (eds). Polycystic ovary syndrome. Baston: Blackwall Scientific; 1992. p. 377-84.

6. Azziz R, Carmina E, Dewailly D, Diamanti-Kandarakis E, Escobar-Morreale HF, Futterweit W, et al. Position statement: criteria for defining polycystic ovary syndrome as a predominantly hyperandrogenic syndrome: an androgen excess society guideline. J Clin Endocrinol Metab. 2006;91(11):4237-45.

7. Azziz R, Woods KS, Reyna R, Key TJ, Knochenhauer ES, Yildiz BO. The prevalence and features of the polycystic ovary syndrome in an unselected population. J Clin Endocrinol Metab. 2004;89:2745-9.

8. Gil-Junior $A B$, Rezende APR, Carmo AV, Duarte EI, Medeiros MMWY, Medeiros SF. Adrenal androgen participation in the polycystic ovary syndrome. Rev Bras Gynecol Obstet. 2010;32:541-8.

9. Payne $A H$, Hales DB. Overview of steroidogenic enzymes in the pathway from cholesterol to active steroid hormones. Endocr Rev. 2004; 25:947-70.

10. Carmina E, Gonzalez F, Chang L, Lobo RA. Reassessment of adrenal androgen secretion in women with polycystic ovary syndrome. Obstet Gynecol. 1995;85:971-6.

11. Rosenfield RL, Barnes RB, Cara JF, Lucky AW. Dysregulation of cytochrome P450c 17 alpha as a cause of polycystic ovary syndrome. Fertil Steril. 1990;53:785-91.

12. Sahin $Y$, Kelestimur F. The frequency of late-onset 21-hydroxylase and $11 \beta$-hydroxilase deficiency in women with polycystic ovary syndrome. Hum Reprod. 1997;137:670-4.

13. Ditkoff EC, Fruzzetti F, Chang L, Stancyzk FZ, Lobo RA. The impact of estrogen on adrenal androgen sensitivity and secretion in polycystic ovary syndrome. J Clin Endocrinol Metab. 1995;80:603-7.

14. Bayoumy HA, Alothman AN. Adrenal contribution to polycystic ovary syndrome. Med Princ Pract. 2001; 10:151-5.

15. New ML, Lorenzen F, Lerner AJ, Kohn B, Oberfield SE, Pollack MS, et al. Genotyping steroid 21-hydroxylase deficiency: hormonal reference data. J Clin Endocrinol Metab. 1983;57:320-6.

16. Willenberg HS, Bahlo M, Schott M, Wertenbruch T, Feldkamp J, Scherbaum WA. Helpful diagnostic markers of steroidogenesis for defining hyperandrogenemia in hirsute women. Steroids. 2008;73:41-6.

17. Bloom MS, Schisterman EF, Hediger ML. Selecting controls is not selecting "normals": design and analysis issues for studying the etiology of polycystic ovary syndrome. Fertil Steril. 2006;86:1-12.

18. Rothman MS, Carlson NE, Xu M, Wang C, Swerdloff R, Lee P, et al. Reexamination of testosterone, dihydrotestosterone, estradiol and estrone levels across the menstrual cycle and in postmenopausal women measured by liquid chromatography-tandem mass spectrometry. Steroids. 2011;76:177-82.
19. Escobar-Morreale HF, Sanchón R, San Millán JL. A prospective study of the prevalence of nonclassical congenital adrenal hyperplasia among women presenting with hyperandrogenic symptoms and signs. J Clin Endocrinol Metab. 2008;93:527-33.

20. Barnes RB, Rosenfield RL, Burnstein S, Ehrmann DA. Pituitary-ovarian responses to nafarelin testing in the polycystic ovary syndrome. N Engl J Med. 1989;320:559-65.

21. Çolak R, Kelestimur F, Unluhizarci K, Bayram F, Sahin Y, Tutus A. A comparison between the effects of low dose $(1 \mu \mathrm{g})$ and standard dose $(250 \mu \mathrm{g})$ ACTH stimulation tests on adrenal P450c17 $\alpha$ enzyme activity in women with polycystic ovary syndrome. Eur J Endocrinol. 2002;147:473-7.

22. Auchus RJ, Lee TC, Miller WL. Cytochrome b5 augments the 17,20-lyase activity of human P450c17 without direct electron transfer. J Biol Chem. 1998;273:3158-65.

23. Moghetti P, Castello R, Negri C, Tosi F, Spiazzi GG, Brun E, et al. Insulin infusion amplifies 17 alpha-hydroxycorticosteroid intermediates response to adrenocorticotropin in hyperandrogenic women: apparent relative impairment of 17,20 lyase activity. $J$ Clin Endocrinol Metab. 1996;81:881-6.

24. Lin D, Black SM, NagahamaY, Miller WL. Steroid 17 alpha-hidroxylase and 17,20-lyase activities of P450c 17: contributions of serine 106 and P450 reductase. Endocrinology. 1993;132:6:2498-506.

25. Nestler JE, Whitfield JB, Williams TY, Zhu G, Condon J, Kirk KM, et al. Genetics of serum dehydroepiandrosterone sulfate and its relationship to insulin in a population-based cohort of twin subjects. J Clin Endocrinol Metab. 2002;87:682-6.

26. Doi SAR, Al-Zaid M, Towers PA, Scott CJ, Al-Shoumer KA. Steroidogenic alterations and adrenal androgen excess in PCOS. Steroids. 2006;71:751-9.

27. Pang S, Lerner A, Stoner E, Levine LS, Oberfield SE, Engel I, et al. Late-onset adrenal steroid 3 beta-hydroxysteroid dehydrogenase deficiency a cause of hirsutism in pubertal ans postpubertal women. J Clin Endocrinol Metab. 1985;60:428-38.

28. Cobin RH, Futterweit W, Fiedler RP,Thornton JC. Adrenocorticotrophic hormone testing in idiopathic hirsutism and polycystic ovarian disease: a test of limited usefulness. Fertil Steril. 1985;44:224-6.

29. Lutfallah C, Wang W, Mason Jl, Chang YT, Haider A, Rich B, et al. Newly proposed hormonal criteria via genotypic proof for type II 3beta-hydroxylase deficiency. J Clin Endocrinol Metab. 2002;87:6:2611-22.

30. Pall M, Azziz R, Beires J, Pignatelli D. The phenotype of hirsute women: a comparison of polycystic ovary syndrome and 21-hydroxylase-deficient nonclassic adrenal hyperplasia. Fertil Steril. 2010;94: 684-9.

31. Trakakis E, Rizos D, Loghis C, Chryssikopoulos A, Spyropoulou $M$, Salamalekis $E$, et al. The prevalence of non-classical congenital adrenal hyperplasia due to 21-hydroxylase deficiency in greek women with hirsutism and polycystic ovary syndrome. Endocr J. 2008;55:33-9.

32. Azziz R, Bradley Jr EL, Potter D, Boots LR. Adrenal androgen excess in women: lack of a role for 17-hydroxylase and 17, 20-lyase dysregulation. J Clin Endocrinol Metab. 1995;80:400-5.

33. Kushnir MM, Rockwood AL, Roberts WL, Pattison EG, Owen WE, Bunker AM, et al. Development and performance evaluation of a tandem mass spectrometry assay for 4 adrenal steroids. Clin Chem. 2006;52:8:1559-67. 